\title{
Modelling Water Absorption in Micronized Lentil Seeds with the Use of Peleg's Equation
}

\author{
Izabela Kuna-Broniowska ${ }^{1}{ }^{\mathbb{D}}$, Agata Blicharz-Kania ${ }^{2, * \mathbb{C}}$, Dariusz Andrejko ${ }^{2}$,

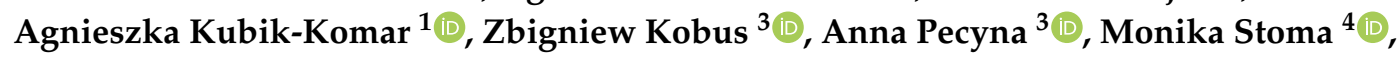 \\ Beata Ślaska-Grzywna ${ }^{2}$ and Leszek Rydzak ${ }^{2}$ \\ 1 Department of Applied Mathematics and Computer Science, University of Life Sciences in Lublin, \\ 20-612 Lublin, Poland; izabela.kuna@up.lublin.pl (I.K.-B.); agnieszka.kubik@up.lublin.pl (A.K.-K.) \\ 2 Department of Biological Bases of Food and Feed Technologies, University of Life Sciences in Lublin, \\ 20-612 Lublin, Poland; dariusz.andrejko@up.lublin.pl (D.A.); beata.grzywna@up.lublin.pl (B.Ś.-G.); \\ leszek.rydzak@up.lublin.pl (L.R.) \\ 3 Department of Technology Fundamentals, University of Life Sciences in Lublin, 20-612 Lublin, \\ Poland; zbigniew.kobus@up.lublin.pl (Z.K.); anna.pecyna@up.lublin.pl (A.P.) \\ 4 Department of Power Engineering and Transportation, University of Life Sciences in Lublin, 20-612 Lublin, \\ Poland; monika.stoma@up.lublin.pl \\ * Correspondence: agata.kania@up.lublin.pl; Tel.: +48-81-531-9646
}

Received: 6 November 2019; Accepted: 25 December 2019; Published: 28 December 2019

\begin{abstract}
The aim of the paper was to investigate the effect of infrared pre-treatment on the process of water absorption by lentil seeds. The paper presents the effects of micronization on the process of water absorption by lentil seeds. As a source of infrared emission, 400-W ceramic infrared radiators ECS-1 were used. The seeds were soaked at three temperature values (in the range from 25 to $75{ }^{\circ} \mathrm{C}$ ) for $8 \mathrm{~h}$, that is, until the equilibrium moisture content was achieved. Peleg's equation was used to describe the kinetics of water absorption by lentil seeds. The results were compared with those obtained in the process of soaking crude seeds. On the basis of the conducted research, it was found that the infrared pre-treatment contributed to a substantial increase in the water absorption rate in the initial period of soaking lentil seeds (especially at $25^{\circ} \mathrm{C}$ ). Infrared irradiation can be an effective method for intensification of lentil seed hydration at an ambient temperature. It should be assumed that, in accordance with the principles of sustainable development, shortening the heating time will significantly reduce the energy consumption and cost of processing lentil seeds.
\end{abstract}

Keywords: legumes; infrared processing; acceleration of the process of hydration; Peleg's equation

\section{Introduction}

Water absorption by plant raw materials is influenced by both the process parameters (e.g., temperature, pressure) and the physical and chemical properties of the raw materials. The impact of the temperature of the soaking process on the rate and amount of absorbed water was investigated by, for example, Maskan [1] and Turhan et al. [2]. Their results clearly demonstrate the role of temperature (in the range from 6 to $100^{\circ} \mathrm{C}$ ) in the water absorption process. An elevated temperature was found to accelerate the water absorption rate in the case of peas, wheat, lupine, soybean, and faba bean.

Research is being carried out to develop a mathematical description of water absorption by granular plant materials. The process of water absorption in some cereal caryopses and legume seeds, that is, wheat, peas, or rice, has been investigated, and a model based mainly on the Fick diffusion equation has been developed [3-5]. However, prediction of the water absorption time based on Fick's law requires a very complex mathematical apparatus, which makes it very inconvenient for practical calculations 
in many cases. Hence, Peleg [6] proposed a two-parameter, non-exponential, empirical equation for modelling the water absorption process in raw materials and food products, as follows:

$$
M_{t}=M_{0} \pm \frac{t}{K_{1}+K_{2} \cdot t}
$$

where

$M_{t}$-Water content after time $\mathrm{t}, \%$ of d.w.;

$M_{0}$-Initial water content, $\%$ of d.w.;

$\mathrm{K}_{1}-$ Constant, $\mathrm{h} \cdot \mathrm{\%}^{-1}$;

$K_{2}$-Constant, $\%^{-1}$.

Equation (1) contains the " \pm " sign. The " + " sign is used to model the water absorption process, and the " - " sign is used to model the drying process.

The main attribute of this equation, compared with other equations, is its simplicity [1]. This formula has been positively verified for several cereal and legume species [2,7-9].

The sorption rate $\mathrm{R}$ can be calculated from the first derivative of Peleg's Equation.

$$
R=\frac{d M}{d t}= \pm \frac{K_{1}}{\left(K_{1}+K_{2} t\right)^{2}}
$$

Peleg's constant $K_{1}$ refers to the initial sorption rate $\left(R_{0}\right.$, i.e., the value of $R$ at $\left.t=t_{0}\right)$.

$$
R_{0}=\left.\frac{d M}{d t}\right|_{t_{0}}= \pm \frac{1}{K_{1}}
$$

At $t \rightarrow \infty$, Equation (4) describes the relationship between the equilibrium moisture content $\left(M_{e}\right)$ and constant $K_{2}$.

$$
\left.M\right|_{t_{\infty}}=M e=M_{0 \pm} \frac{1}{K_{2}}
$$

Linearization of Equation (1) gives the following formula:

$$
\frac{t}{M_{t}-M_{0}}=K_{1}+K_{2} t .
$$

Adjustment of the equation of such a line allows estimation of parameters $K_{1}$ and $K_{2}$.

The value of constant $K_{1}$ provides information about the mass transfer rate during the water absorption process, that is, the lower the $K_{1}$ value, the higher the water absorption rate $[2,7,10$, 11]. While the $K_{1}$ coefficient has been relatively precisely defined in many publications, there is a large discrepancy as far as the significance of constant $K_{2}$ is concerned. In investigations of water absorption by wheat-based products, Maskan [1] has found that constant $K_{2}$ refers to the maximum water absorption capacity, that is, the water absorption capacity increases at lower $K_{2}$ values. Similar conclusions were formulated by Abu-Ghannam and McKenna [7], as well as Sayar et al. [11]. However, other authors [10,12-14] did not confirm these findings.

Reduction of energy consumption in economy is the most efficient and best-recognized way of implementing the principle of sustainable development. In addition, from the consumer's point of view, the use of legume seeds is determined by the time of preparation of ready-to-eat products. Therefore, seed pre-treatment should ensure the shortest time of the subsequent hydrothermal treatment thereof (e.g., soaking, cooking). As suggested by Cenkowski and Sosulski [15], thermal infrared pre-treatment of seeds applied prior to soaking or cooking can shorten these treatments and provide instant-type products.

Infrared radiation is very widely used in various industries. In the food industry, it is used primarily for drying and pre-treatment of food. The micronization process allows, for example, 
reducing the content of anti-nutritional substances in legume seeds or increasing the efficiency of pressing oilseeds. Owing to the specific mechanism of heat transport during micronization, the heat and mass exchange conditions are definitely more favourable than when using traditional heat treatment methods. In practice, it results in more effective operation, and thus reduction of the duration of the process [16-18].

However, the available literature provides no reports on the possibility of using Peleg's equation to determine the rate of water absorption by micronized legumes.

Therefore, the paper presents an attempt to investigate the effect of infrared pre-treatment on the process of water absorption by lentil seeds.

\section{Materials and Methods}

\subsection{Research Material}

The lentil seeds (variety Anita) used in the experiment were purchased at a local supermarket in Lublin. Prior to the determinations, the raw material was purified by the removal of cracked and damaged seeds. It was stored in closed plastic containers at a temperature of $5{ }^{\circ} \mathrm{C}$. Before further measurements, the lentil seeds were placed at room temperature (approximately $23^{\circ} \mathrm{C}$ ) for $3 \mathrm{~h}$.

\subsection{Measurement of Initial Moisture Content}

The first stage of the research involved determination of the initial moisture content of the raw material $(\mathrm{W})$ using the drying method. The material was dried for $3 \mathrm{~h}$ in a laboratory dryer SLN 15 STD at a temperature of $103^{\circ} \mathrm{C}$. The total protein content in the material was determined with the Kjeldahl method using an automated Foss Kjeltec 8400 distillation unit, and the total fat content was determined using a Soxtec 8000 apparatus with AN 310 software (Table 1).

Table 1. Effect of selected components in lentil seeds calculated per dry weight.

\begin{tabular}{|c|c|c|}
\hline \multicolumn{2}{|c|}{ Nutrients } & Content [\%] \\
\hline \multicolumn{2}{|c|}{ Protein } & $22.01 \pm 0.53$ \\
\hline \multicolumn{2}{|c|}{ Fat } & $0.90 \pm 0.02$ \\
\hline & Crude seeds & $8.40 \pm 0.17$ \\
\hline Moisture & Micronized seeds & $6.00 \pm 0.20$ \\
\hline
\end{tabular}

\subsection{Micronization Process}

A portion of seeds was subjected to the micronization process. As a source of infrared radiation emission, 400-W ceramic infrared radiators ECS-1 were used. These temperature radiators supplied by electricity $(230 \mathrm{~V})$ have a small fraction of visible radiation (dark radiators) in the spectrum and heat the entire plane uniformly (plane radiators) (Figure 1). The average temperature of the filament is approximately $500{ }^{\circ} \mathrm{C}$ and the emission wavelength is $\lambda=2.5-3.0 \mu \mathrm{m}$. The seeds were heated for $120 \mathrm{~s}$ at a temperature on the seed surface of $150^{\circ} \mathrm{C}$. Next, the seeds were left to dry in open containers at room temperature for $3 \mathrm{~h}$. 


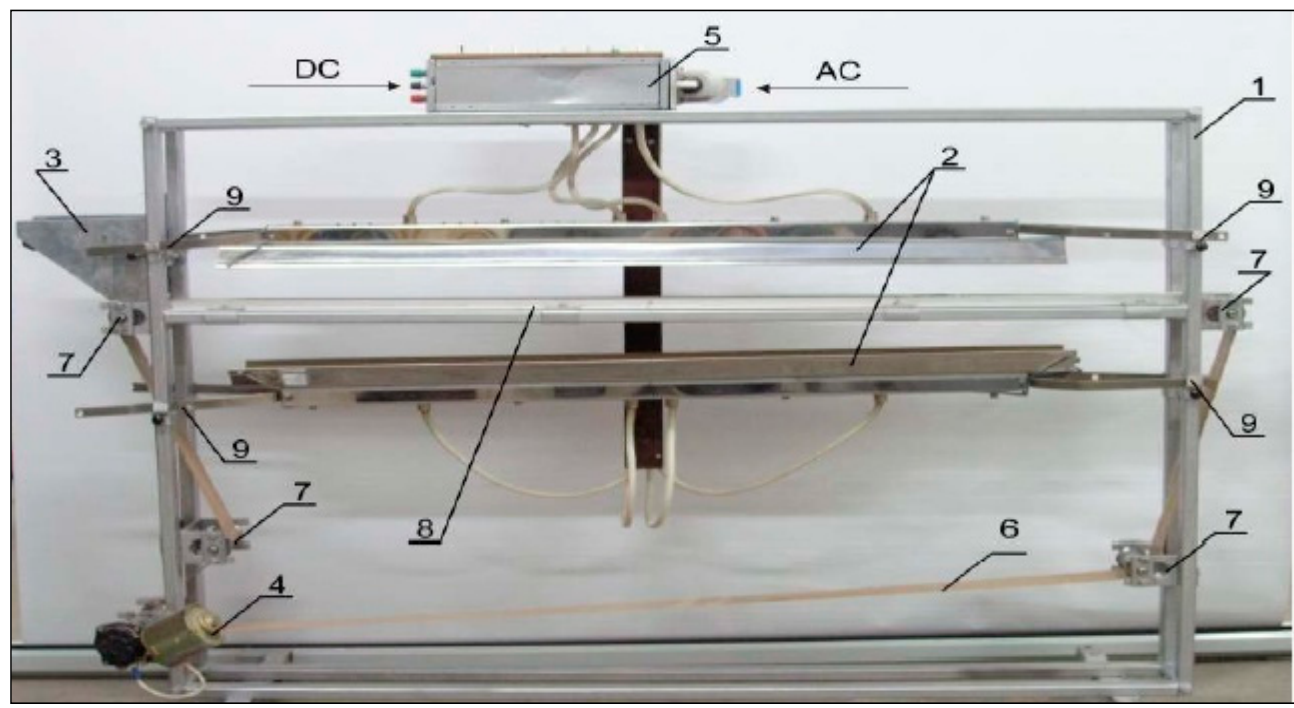

Figure 1. Laboratory device for infrared treatment of granular plant raw materials: DC - direct current, AC - alternating current, 1-frame, 2-infrared radiators, 3-feeding tank, 4-DC motor, 5-control unit, 6-conveyor belt, 7-rollers, 8-heating zone, 9-adjustment of the position of the heads.

\subsection{Measurement of the Water Content}

At $24 \mathrm{~h}$ after the micronization process, the moisture content in the micronized seeds was determined and the crude and micronized seeds were soaked. Samples of randomly selected seeds (excluding cracked and damaged seeds) weighing approximately $0.5 \mathrm{~g}\left(\mathrm{M}_{\mathrm{m}}\right)$ were placed in special baskets with a perforated wall and bottom. The material was soaked in a water bath (using distilled water) within a time range from $5 \mathrm{~min}$ to $8 \mathrm{~h}$ at a temperature of $25^{\circ} \mathrm{C}, 50^{\circ} \mathrm{C}$, and $75^{\circ} \mathrm{C}$.

After the time intervals adopted in the experiment, the samples were removed, the excess water was dried on filter paper, and the water content in the seeds was determined.

The water content relative to dry weight was calculated using Equation (6):

$$
M_{t}=\frac{M_{1}+M_{H_{2} \mathrm{O}}}{M_{1}} 100 \%,
$$

where

$M_{t}$-Water content after time $\mathrm{t}, \%$ relative to dry weight [\%];

$\mathrm{M}_{\mathrm{H} 2 \mathrm{O}}$-Water weight after time $\mathrm{t}[\mathrm{g}]$;

$M_{1}$-Dry weight [g].

The dry weight was calculated based on Equation (7):

$$
M_{1}=M_{m} \cdot(100 \%-W),
$$

where

$M_{m}$-Initial weight of the material [g];

W-Moisture [\%].

The determinations were carried out in triplicate.

\subsection{Statistical Analysis}

The data were analysed statistically. A significance level of $\alpha=0.05$ was assumed for inference. The analysis was carried out using analysis of variance (ANOVA) (StatSoft Polska, Poland, Cracow). 


\section{Results and Discussion}

Table 1 shows the effect of selected components in lentil seeds calculated per dry weight. The lentil seeds were characterised by typical levels of essential nutrients, for example, protein and fat. For comparison, the investigations of the chemical composition of lentils conducted by Hefnawy [19]

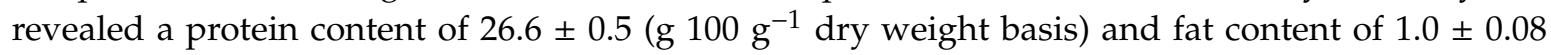
(g $100 \mathrm{~g}^{-1}$ dry weight basis). Similarly, the water content in the crude seeds corresponded to the values demonstrated by other authors $[19,20]$.

Figure 2 shows the effect of temperature and time on changes in the water content in the crude lentil seeds. Analysis of variance revealed a significant effect of both of these factors on the water content in the soaked seeds. The water absorption rate decreased with the time of soaking. The highest water content, that is, $142 \%$, was observed after $5 \mathrm{~h}$ of soaking of lentil seeds at a temperature of $50^{\circ} \mathrm{C}$. Further, soaking did not change the water content in the treated lentil seeds significantly. The values obtained in this study are in agreement with the results reported by other authors. The mean water content in seeds was estimated at $129 \%$ by Chopra and Prasad [21], 140\% by Pan and Tangratanavalee [22], and $147 \%$ by Quicazán et al. [8].

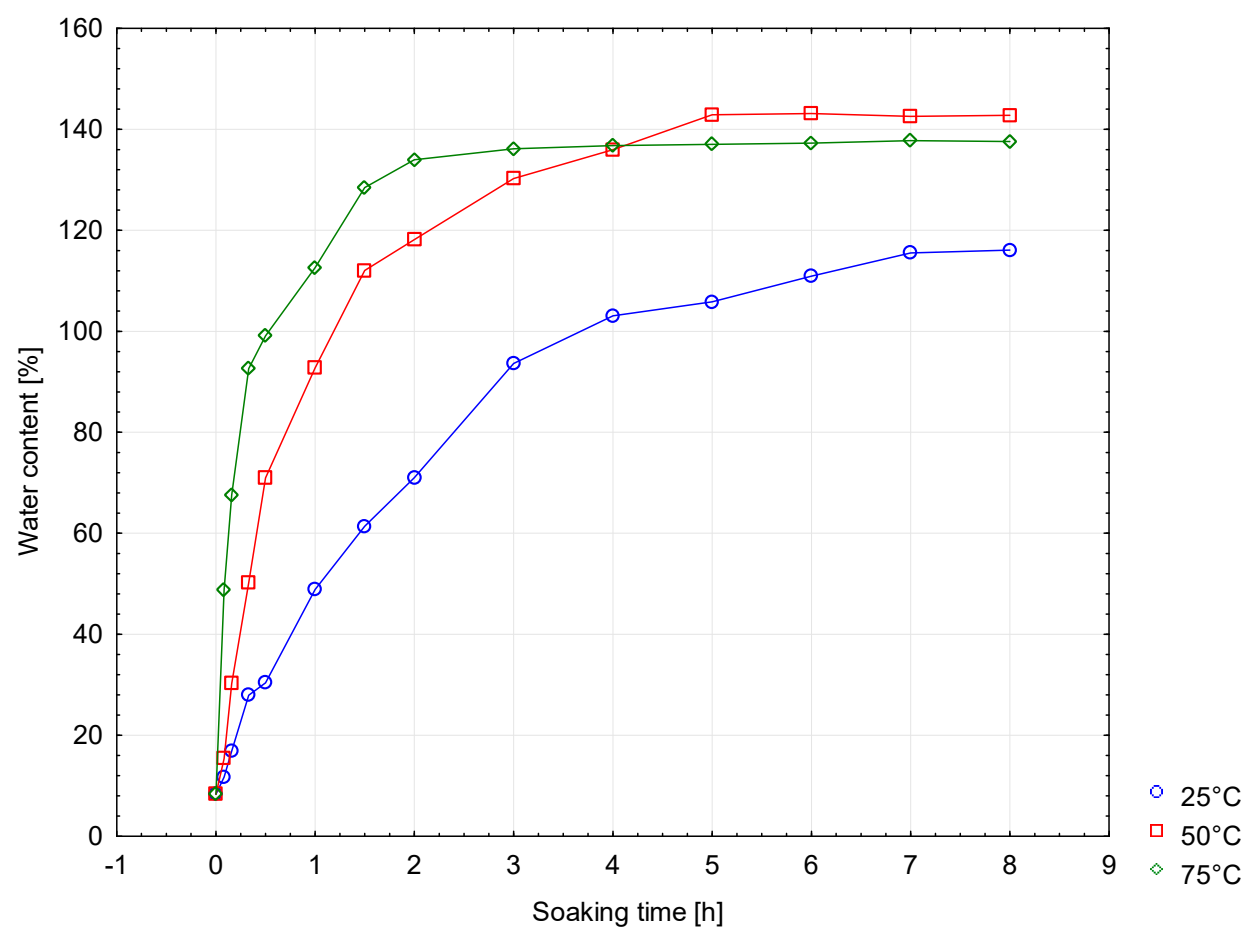

Figure 2. Effect of temperature and duration of soaking on the water content in crude lentil seeds.

In the initial soaking period, the lentil seeds exhibited the lowest water absorption rate at the temperature of $25{ }^{\circ} \mathrm{C}$. An increase in the temperature to $50{ }^{\circ} \mathrm{C}$ and then $75{ }^{\circ} \mathrm{C}$ resulted in an increase in this parameter. After $3 \mathrm{~h}$ of soaking at $75^{\circ} \mathrm{C}$, the lentil seeds reached a maximum moisture level of $138 \%$. Seeds soaked at the temperature of $50{ }^{\circ} \mathrm{C}$ absorbed water at a slower rate and reached the maximum level later, but this was by $4 \%$ higher than the value obtained at $75{ }^{\circ} \mathrm{C}$. These results are in agreement with the findings presented by other authors. Quicazán et al. [8] reported a slightly higher level of water in seeds soaked at a temperature of $40^{\circ} \mathrm{C}$ than the water content in seeds soaked at $80^{\circ} \mathrm{C}$. This phenomenon may be associated with the more intensive denaturation of proteins at a higher temperature, which in turn may reduce the final capacity of water absorption in lentil seeds.

Table 2 shows Peleg's coefficients and the goodness of fit of the model to the experimental data. It was shown that the $K_{2}$ parameter value changed slightly with the soaking temperature. This is in line with the results obtained by Sopade et al. [14], in experiments of cereal grain hydration, 
and Abu-Ghannam and McKenna [7], who investigated the process of hydration of bean seeds. The values of the $K_{1}$ parameter declined with an increase in the temperature of soaking. This trend is in good agreement with the results reported by other authors. In experiments involving soybean seed soaking, Quicazán et al. [8] observed a negative correlation between the soaking temperature and the value of the $K_{1}$ parameter. The dependence of $K_{1}$ on $T$ (absolute temperature) is expressed by Equation (8).

$$
\mathrm{K}_{1}=0.0006 \mathrm{~T}^{2}-0.4452 \mathrm{~T}+77.358
$$

Table 2. Parameters of Peleg's model for hydration of crude lentil seeds at three temperatures.

\begin{tabular}{cccccccc}
\hline Parameter & $\boldsymbol{T}$ & $\begin{array}{c}\text { Soaking } \\
\text { Time }\end{array}$ & $\boldsymbol{K}_{\mathbf{1}}$ & $\mathbf{1} / \boldsymbol{K}_{\mathbf{1}}$ & $\boldsymbol{K}_{\mathbf{2}}$ & $\boldsymbol{R}^{\mathbf{2}}$ & $\boldsymbol{E}$ \\
\hline Unit & ${ }^{\circ} \mathrm{C}$ & $\mathrm{h}$ & & & & & $\%$ \\
\hline Result & 25 & $0-8$ & 1.6845 & 0.59365 & 0.6893 & 0.9960 & 3.93 \\
& 50 & $0-8$ & 0.5183 & 1.92938 & 0.6567 & 0.9957 & 6.08 \\
& 75 & $0-8$ & 0.1543 & 6.48088 & 0.7461 & 0.9952 & 1.94 \\
\hline
\end{tabular}

Notes: $R^{2}$-fit of the model; $E$ - goodness of fit of the model.

Figure 3 shows the effect of the temperature and soaking time on changes in the water content in the micronized lentil seeds. The temperature and soaking time contributed to an increase in the water content in the micronized lentil seeds. In the initial soaking period, the lentil seeds exhibited the lowest rate of water absorption at a temperature of $25^{\circ} \mathrm{C}$. The increase in the temperature to $50{ }^{\circ} \mathrm{C}$ and then $75^{\circ} \mathrm{C}$ increased the water absorption rate. After $4 \mathrm{~h}$ of soaking at both $50^{\circ} \mathrm{C}$ and $75^{\circ} \mathrm{C}$, the lentil seeds achieved the maximum moisture level. The highest water content, that is, $138 \%$, was observed at the temperature of $75^{\circ} \mathrm{C}$.

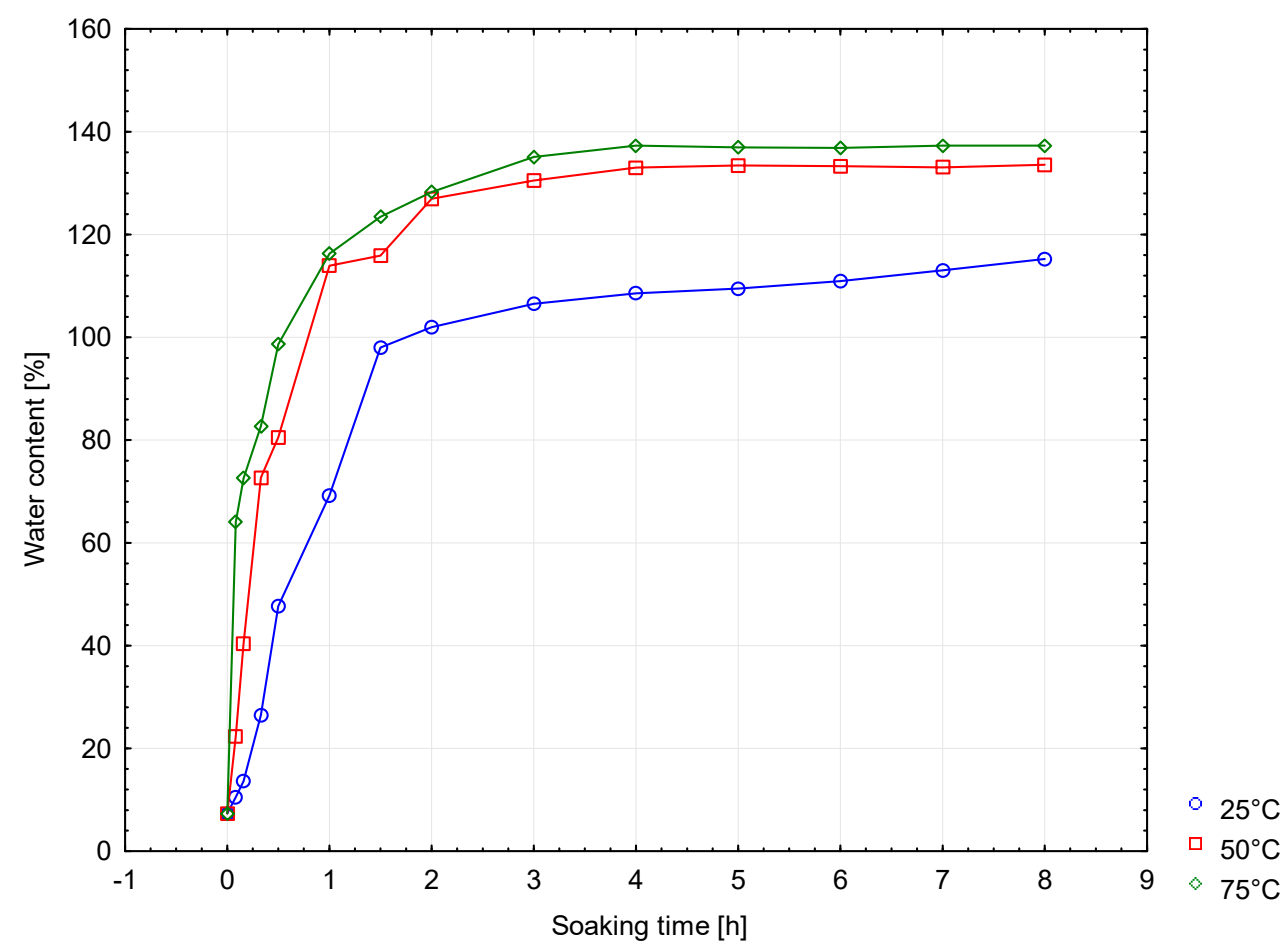

Figure 3. Effect of temperature and soaking time on changes in the water content in the micronized lentil seeds. 
Table 3 shows Peleg's model coefficients and the goodness of fit of the model to the experimental data for the micronized seeds. The values of the $K_{1}$ parameter declined with the increase in the soaking temperature. In comparison with the crude lentil seeds, the values of the $K_{1}$ coefficients were significantly lower at all tested temperatures. This indicates a higher rate of water absorption in the micronized seeds. The dependence of $K_{1}$ on $T$ (absolute temperature) is expressed by Equation (9):

$$
K_{1}=0.0003 \mathrm{~T}^{2}-0.1838 \mathrm{~T}+32.056
$$

Table 3. Parameters of Peleg's model for micronized lentil hydration at three temperatures.

\begin{tabular}{cccccccc}
\hline Parameter & $\boldsymbol{T}$ & $\begin{array}{c}\text { Soaking } \\
\text { Time }\end{array}$ & $\boldsymbol{K}_{\mathbf{1}}$ & $\mathbf{1} / \boldsymbol{K}_{\mathbf{1}}$ & $\boldsymbol{K}_{\mathbf{2}}$ & $\boldsymbol{R}^{\mathbf{2}}$ & $\boldsymbol{E}$ \\
\hline Unit & ${ }^{\circ} \mathrm{C}$ & $\mathrm{h}$ & & & & & $\%$ \\
\hline Result & 25 & $0-8$ & 0.7801 & 1.28189 & 0.7977 & 0.9698 & 17.38 \\
& 50 & $0-8$ & 0.2920 & 3.42466 & 0.7299 & 0.9895 & 6.06 \\
& 75 & $0-8$ & 0.1345 & 7.43494 & 0.7565 & 0.9791 & 4.18 \\
\hline
\end{tabular}

Notes: $R^{2}$-fit of the model; E-goodness of fit of the model.

The values of the $K_{2}$ coefficient in the case of the micronized seeds changed as in the case of the crude seeds. The highest $K_{2}$ coefficient was noted at the temperature of $25^{\circ} \mathrm{C}$; next, it declined to the lowest value at $50{ }^{\circ} \mathrm{C}$ and reached an intermediate value at $75^{\circ} \mathrm{C}$. In general, all values of the $K_{2}$ coefficient for the micronized seeds were slightly lower than the $K_{2}$ values for the crude seeds. This was reflected in the final water content in the micronized seeds, which was slightly lower than that observed in the crude seeds.

\section{Conclusions}

The paper presents the effect of the infrared radiation treatment on the kinetics of water absorption by lentil seeds. The results were compared with the process of soaking crude seeds. In both cases, the changes in the water content were described using Peleg's model. An impact of the infrared pre-treatment on the water absorption rate and content in lentil seeds was demonstrated. The infrared pre-treatment largely contributes to an increase in the water absorption rate in the initial period of soaking lentil seeds. This is particularly evident at a temperature of $25^{\circ} \mathrm{C}$, at which micronization reduces the time required for achievement of $100 \%$ water content by more than half in comparison with crude seeds. At higher temperatures, these differences are smaller, that is, $40 \%$ and $17 \%$, for the temperatures of $50{ }^{\circ} \mathrm{C}$ and $75^{\circ} \mathrm{C}$, respectively. The impact of micronization on the final water content in lentil seeds depends on the soaking temperature. A statistically significant effect of micronization on the water content was found at $25^{\circ} \mathrm{C}$ (reduction of constant $K_{1}$ from 1.6845 to 0.7801 ). Slightly smaller changes in the rate of water absorption were observed at $50^{\circ} \mathrm{C}$ and $75^{\circ} \mathrm{C}$.

Infrared treatment can be successfully used to accelerate the process of hydration of lentil seeds at an ambient temperature. As a consequence, limiting the damaging impact of production on the environment will ensure sustainable consumption and processing of legumes. The results obtained in the present study can be regarded as preliminary research on the possibility of using micronization to accelerate the absorption of water by seeds of other plants, including cereals.

Author Contributions: Conceptualization, I.K.-B., D.A. and M.S.; Data curation, A.P.; Formal analysis, I.K.-B. and Z.K.; Investigation, A.B.-K. and A.P.; Methodology, A.B.-K., D.A., A.K.-K. and B.Ś.-G.; Project administration, M.S.; Software, I.K.-B. and A.K.-K.; Supervision, I.K.-B. and D.A.; Validation, A.K.-K.; Visualization, A.B.-K., Z.K. and B.Ś.-G.; Writing-original draft, A.B.-K., Z.K. and A.P.; Writing-review \& editing, D.A., A.K.-K. and L.R. All authors have read and agreed to the published version of the manuscript.

Funding: This research received no external funding. 
Conflicts of Interest: The authors declare no conflict of interest.

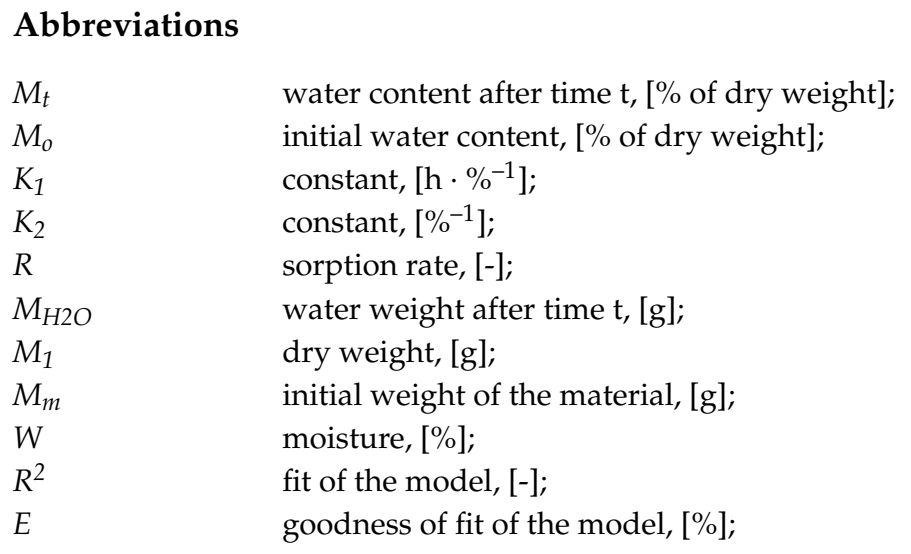

\section{References}

1. Maskan, M. Effect of processing on hydration kinetics of three wheat products of the same variety. J. Food Eng. 2002, 52, 337-341. [CrossRef]

2. Turhan, M.; Sayar, S.; Gunasekaran, S. Application of Peleg model to study water absorption in chickpea during soaking. J. Food Eng. 2002, 53, 153-159. [CrossRef]

3. Cunningham, S.E.; McMinn, W.A.M.; Magee, T.R.A.; Richardson, P.S. Modelling water absorption of pasta during soaking. J. Food Eng. 2007, 82, 600-607. [CrossRef]

4. Montanuci, F.D.; Perussello, C.A.; de Matos Jorge, L.M.; Jorge, R.M.M. Experimental analysis and finite element simulation of the hydration process of barley grains. J. Food Eng. 2014, 131, 44-49. [CrossRef]

5. Munson-McGee, S.H.; Mannarswamy, A.; Andersen, P.K. D-optimal designs for sorption kinetic experiments: Cylinders. J. Food Eng. 2011, 104, 202-207. [CrossRef]

6. Peleg, M. An empirical model for the description of moisture sorption curves. J. Food Sci. 1988, 53, 1216-1217, 1219. [CrossRef]

7. Abu-Ghannam, N.; McKenna, B. The application of Peleg's equation to model water absorption during the soaking of red kidney beans (Phasedus vulgaris L.). J. Food Eng. 1997, 32, 391-401. [CrossRef]

8. Quicazán, M.C.; Caicedo, L.A.; Cuenca, M. Applying Peleg's equation to modelling the kinetics of solid hydration and migration during soybean soaking. Ing. Investig. 2012, 32, 53-57.

9. Sopade, P.A.; Xun, P.Y.; Halley, P.J.; Hardin, M. Equivalence of the Peleg, Pilosof and Singh-Kulshrestha models for water absorption in food. J. Food Eng. 2007, 78, 730-734. [CrossRef]

10. Hung, T.V.; Liu, L.H.; Black, R.G.; Trewhella, M.A. Water absorption in chickpea (C. arietinum) and field pea (P. sativum) cultivars using the Peleg model. J. Food Sci. 1993, 58, 848-852. [CrossRef]

11. Sayar, S.; Turhan, M.; Gunasekaran, S. Analysis of chickpea soaking by simultaneous water transfer and water-starch reaction. J. Food Eng. 2001, 50, 91-98. [CrossRef]

12. Maharaj, V.; Sankat, C.K. Rehydration characteristics and quality of dehydrated dasheen leaves. Can. Agric. Eng. 2000, 42, 81-85.

13. Sopade, P.A.; Obekpa, J.A. Modeling water absorption in soybean, cowpea and peanuts at three temperatures using Peleg's equation. J. Food Sci. 1990, 55, 1084-1087. [CrossRef]

14. Sopade, P.A.; Ajisegiri, E.S.; Badau, M.H. The use of Peleg's equation to model water absorption in some cereal grains during soaking. J. Food Eng. 1992, 15, 269-283. [CrossRef]

15. Cenkowski, S.; Sosulski, F.W. Cooking characteristics of split peas treated with infrared heat. Trans. ASAE 1998, 41, 715-720. [CrossRef]

16. Khattab, R.Y.; Arntfield, S.D. Nutritional quality of legume seeds as affected by some physical treatments 2. Antinutritional factors. Lebensm. Wiss. Technol. 2009, 42, 1113-1118. [CrossRef]

17. Krajewska, M.; Ślaska-Grzywna, B.; Andrejko, D. Effect of Infrared Thermal Pre-Treatment of Sesame Seeds (Sesamum Indicum L.) on Oil Yield and Quality. Ital. J. Food Sci. 2018, 30, 487-496. [CrossRef] 
18. Sobczak, P.; Zawiślak, K.; Panasiewicz, M.; Mazur, J.; Kocira, S.; Żukiewicz-Sobczak, W. Impact of Heat Treatment on the Hardness and Content of Anti-Nutritious Substances in Soybean Seeds. Carpath. J. Food Sci. Technol. 2018, 10, 46-52.

19. Hefnawy, T.H. Effect of processing methods on nutritional composition and anti-nutritional factors in lentils (Lens culinaris). Ann. Agric. Sci. 2011, 56, 57-61. [CrossRef]

20. Boye, J.I.; Aksay, S.; Roufik, S.; Ribéreau, S.; Mondor, M.; Farnworth, E.; Rajamohamed, S.H. Comparison of the functional properties of pea, chickpea and lentil protein concentrates processed using ultrafiltration and isoelectric precipitation techniques. Food Res. Int. 2010, 43, 537-546. [CrossRef]

21. Chopra, R.; Prasad, D.N. Standardization of soaking conditions for soybean seeds/cotyledons for improved quality of soymilk. Indian J. Anim. Sci. 1994, 64, 405-410.

22. Pan, Z.; Tangratanavalee, W. Characteristics of soybeans as affected by soaking conditions. Lebensm. Wiss. Technol. 2003, 36, 143-151. [CrossRef]

(C) 2019 by the authors. Licensee MDPI, Basel, Switzerland. This article is an open access article distributed under the terms and conditions of the Creative Commons Attribution (CC BY) license (http://creativecommons.org/licenses/by/4.0/). 